\author{
Лех Церан \\ Uniwersytet Łódzki \\ janpembert@live.com
}

\title{
ПРИНОСЪТ НА ИВАН БОГОРОВ КЪМ ОФОРМЯНЕТО НА БЪЛГАРСКАТА ПРЕСА ПРЕЗ ХІХ ВЕК
}

Българската преса е една от най-бързо развиващите се на света. В сравнение с другите, като например с италианската, германската или чешката - която е една от най-старите в Европа [Młynarski 1962: 3] тя има много кратка история, обаче преживява интензивен растеж и само в продължение на няколко години се изравнява с останалите. Нейната история започва през Българското национално възраждане [Dąbek-Wirgowa 1980: 79]. През този период многобройни дейци създават първите списания и вестници на български език. Като един от най-важните основатели на българската преса можем да определим Иван Богоров. Той е автор на няколко списания, но най-важното е, че той е автор на първите вестници, написани на български език. Те в голяма степен дефинират посоката, в която се развива българската журналистика през XIX век. В моята статия ще се спра на най-важните му вестници и списания - които в най-голяма степен допринасят за развоя на тази дисциплина, тоест „Български орел”, „Цариградски вестник”, „Български книжици”, „Чистобългарска наковалня за сладкодумство”, но също ще спомена няколко други негови списания за да получим по-точна представа за въпроса представен в заглавието.

Преди да се съсредоточим върху ролята на Иван Богоров за формирането на българската журналистика, би трябвало да се спрем на неговия живот. Иван Богоров не заема водещо място сред възрожденците като Найден Геров, Георги Раковски, Петко Р. Славейков или Христо Ботев, но е възприеман не само като един от основателите на българската преса, но също като един от най-видните български енциклопедисти и езикови пуристи.

Той е роден през януари 1821 година в Карлово в Османската империя - намиращо се сега в централната част на Република България. Завършва основното си образование в родното си място и после продължава обучението си в Цариград. После заминава за Одеса, където постьпва в Ришельовската гимназия. През 1845 година заминава за Германия, по-точно за Лайпциг - за 
да продължи образованието си. Там издава първия брой на първия български вестник под заглавието „Български орел” [Константинов, Минков, Великов 1961: 94] - защото според него българският народ културно изостава в сравнение с другите в Европа и той трябва да се сравни с тях чрез книгите, списанията и вестниците [Młynarski 1962: 131]. Поради липса на средства се премества в османската столица, където през 1848 година с помощта на Русия започва да издава „Цариградски вестник”. След три години заминава за Букурещ, после става учител в Шумен и след това заминава за Париж, където учи медицина [Константинов, Минков, Великов 1961: 94], която не завършва, обаче това не му пречи да издава медицински книги, като например „Селският лекар” от 1875 година [Młynarski 1962: 130]. През 1858 година се връща в Цариград, където започва да редактира списанието „Български книжици". Оттам отива в Пловдив и приема пост на градски лекар и през 1862 година започва да издава „Журнал за наука, занаят и търговия”. През 1873 година - след пьтуване до Одеса, Москва, Петербург и Виена отива за кратко време в Букурещ, за да стане редактор на вестник „Народност”. После се връща в Цариград, където започва да редактира списанието „Турция”. След една година се връща в Пловдив и там издава списанието „Книговище за прочитане”. През 1875 година взима участие в сръбско-турската война като военен лекар. След две години заедно с руските войски влиза в България и става преводач в Свищов. Заболява и заминава за Виена на лечение, обаче през 1878 година отново се врьща в Пловдив, където започва да издава последното си списание „Чистобългарска наковалня за сладкодумство”. През 1879 година отпечатва в него автобиографията си „Живота ми, описан от мене“, която е издадена като отделна книжка през 1887 година. После той заминава за София, където умира на 20 октомври 1892 година [Константинов, Минков, Великов 1961: 94-95; Коларов 2009: 45].

Когато говорим за българската преса не можем да забравим за „Любословие", тоест пьрвото българско списание, създадено от Константин Фотинов. Той бидейки в Смирна забелязва, че представителите на различните народи - турци, гърци, арменци и евреи, развият своята преса и постоянно издават списания и вестници [Константинов, Минков, Великов 1961: 95]. „Любословие” е първо издадено през 1842 - само като пробен брой, после като редовно списание от 1844 до 1846 година. Главната му тема е образованието на българите - включвайки въпроса за училищата, обучението на жените, новините за техническите изобретения и така нататьк. „Любословие” е базирано на образователните списания в Гьрция [Dąbek-Wirgowa 1980: 78-79]. Главната причина за неговия неуспех е използването на архаичната форма на българския език, понякога наричан дори като старобългарски или църковнославянски език [Crampton 1997: 64, Młynarski 1962: 130].

Две години след издаването на първия брой на „Любословие” Иван Богоров създава вече споменатия „Български орел”. Това е първият български вестник. Издаван е през 1846-1847 година - в три броя [Dąbek-Wirgowa 1980: 79], обаче според информацията, която се появява в първия брой - изданията 
на „Български орел” трябва да се появяват два пъти месечно [Młynarski 1962: 130]. Първият му брой е издаден на 20 април 1848 година, под заглавието „Бљлгарскый орелъ. Извђстникъ гражданскй, тжрговскй и книжовенъ.” Иван Богоров по съвет на Васил Априлов променя името на вестника на такова, което е по-малко бунтарско и неговият втори брой излиза като „Бљлгарскый народенъ извъстникъ.” [Młynarski 1962: 130]. В началото на 1847 година е издаден последният брой на вестника със старото заглавие „Бљлгарскіетъ орелъ. Извъстникъ гражданскй, тжрговскй и книжовенъ.”. В програмата на вестника Иван Богоров предвижда да има повече такива неща, от които даскалите по нашата школа да придобият нещо за изтащението на деиата и затова, той иска да дава на читателите му културно и националноидентификационното образование (по същия модел, както е в „Любословие”) [Гетова 2005: 118]. Въпреки че главните теми на вестника са образование, славистика и търговия, негов голям дял са патриотичните и славянофилските текстове за политика. „Български орел” е създаден по модела на информационните вестници, които са издавани в Европа [Młynarski 1962: 131]. Той съдържа такива раздели, като напр. новини, приказки, смешливи приказвания и народни песни. Иван Богоров издава вестника и пише за него статии под псевдоним „Иванчо Андреов”. В сравнението с „Любословие” вестникът е написан на жив език, обаче като него не получава голям успех и бързо спира да е издаван. Обаче трябва да отбележим, че главно поради това, че е издаван далеч от българските земи [Dąbek-Wigrowa 1980: 79].

Точно една година след последния брой на „Български орел”, тоест през 1848 година Иван Богоров [Dąbrek-Wigrowa 1980: 79] и Александьр Екзарх с помощта на Русия издават „Цариградски вестник” [Wasilewski 1988: 151]. Той в голяма степен е духовен наследник на „Българския орел”, защото в голяма степен новият вестник използва неговите схеми и неговата програма [Młynarski 1962: 131], обаче в сравнение с него и „Любословие” получава голям успех и става един от най-важните информационни източници за българите. Като първия вестник на Богоров той е написан на жив език, обаче едновременно с това има по-чести издания и е публикуван близо до българските земи - както показва неговото име - в османската столица Цариград, където по това време живеят към шестдесет хиляди българи [Młynarski 1962: 131]. Той е първият вестник писан на български език и издаван дълго време [Crampton 1997: 64-65] - издаван е в периода от 1 януари 1848 до 15 декември 1862, тоест петнайсет години [Młynarski 1962: 131]. Иван Богоров става негов първи редактор и изпълнява тази функция до 1851 година, когато ролята започва да изпълнява Александър Екзарх. Вестникът в голяма степен защитава църковните интереси на българите в Османската империя [Константинов, Минков, Великов 1961: 94], обаче едновременно с това показва дискретна симпатия към Русия - за да получава от нея материална помощ [Wasilewski 1988: 151]. Във вестника освен статии се публикуват и художествени текстове - включвайки български адаптации на чужди творби, като Чудесиите на Робинзон Крузо на Даниел Дефо и Еничерите на Мор Йокай, но също и нови 
произведения като например стихотворенията на Добри Чинтулов и Петко Славейков [Радев 2007: 201]. Йордан Хаджиконстантинов Джинот до голяма степен сътрудничи на този вестник, пишейки многобройни статии, бележки и също литературни творби [Георгиев 1980: 198]. След напускането на Иван Богоров „Цариградски вестник” сменя своето отношение към тогавашната политика и заема консервативна и негативна позиция относно стремежа на българите към независимост, защото списанието започва да си сътрудничи с грьцката патриаршия. Това е причина за загубата на неговата популярност [Młynarski 1962: 131-132]. Списанието след Кримската война (1853-1856) пак сменя своето отношение към политиката и въпроса за независимостта на България. По това време има около 60 вестника и 30 списания на български език и само „Цариградски вестник” в сравнение с тях няма отношение към българските национални проблеми, които по това време стават най-актуални и най-интересни за читателите. Като резултат те спират да купуват новите му издания. Липсата на позиция на вестника става главен фактор за неговото фиаско и на 15 декември 1862 Александър Екзарх издава последния му брой [Młynarski 1962: 133].

Иван Богоров след седемгодишното си пътуване в Букурещ, Шумен и Париж се врьща в Цариград през 1858 година и там започва да редактира новосъздаденото списание „Български книжици” - оригиналното му заглавие е „Блъгарскы Книжици”. Трябва да подчертаем, че той не е негов основател, а така наречената „Книжовна дружина” [Младенов 1929]. Първият му редактор е Димитьр Мутев - един от тогавашните просветни дейци, автор на годишния сборник „Месецослов” и преводач на романа от Хариет Бичър Стоу под заглавието Чичо Томовата колиба (на английски Uncle Tom 's Cabin). Главната цел на „Български книжици” е разискването на обществени вьпроси, политика, литература, история и научни знания. Включва оригинални и преведени статии [Каравелов 1985: 20] и стихотворения от автори като Сава Филаретов, Петко Славейков и Константин Миладинов. През 1860 година Васил Друмев публикува в списанието първата оригинална българска повест „Нещастна фамилия” [Леков 2003: 114]. Първият брой на „Български книжици" излиза на 1 януари 1858 година, издавано е два пьти месечно - трябва да подчертаем, че в по-късните години това правило не се спазва и списанието е издавано напр. три или пет пъти месечно. През 1862 година „Български книжници” спира да е издавано [Боршуков 1976: 120].

В края на 1864 година в отоманската столица Иван Богоров издава свой нов вестник - „Турция“. Той публикува в него своите документални репортажи и пътеписи, които са възприемани като едни от най-добрите му. „Турция“ обаче не получава голям успех и затова през лято на 1873 година вестникът е спрян. Иван Богоров, загубил надежда за успех в отоманската столица заминава за Пловдив, за да започне да издава новото си списание [Коларов 2009: 56-57].

Новото списание на Иван Богоров под заглавие „Книговище за прочитане“" излиза през 1874 година. Любопитен е фактът, че името му съдържа 
измислена от Богоров дума книговище. Той обяснява, че тя излиза от думата книга, която според него има осем значения. Новата дума е създадена по образец на вече съществуващите думи, като зимовище, а нейното значение е „всякоя лавица с няколко книги, натрупани или накитени с ред“, „всяка лавица с няколко полици, сгодна да се наредят там доста книги“ или „книгите, които се намират в една сграда“. Това ни показва Богоровото отношение към езика - тоест трябва да бъде изчистен от чужда лексика. Авторът се съсредоточава върху този въпрос в следващото си списание. За да популяризира „Книговище за прочитане“ (и издадената по същото време книга „Селският доктор“) Иван Богоров пътува навред из България [Коларов 2009: 57].

Вече през първите години след освобождението на България дейността си започват езиковите пуристи, които искат да изчистят българския език от чужди думи. Един от тях е Иван Богоров, който през 1878 година, тоест след третото си пътуване започва да издава своето ново списание „Чистобългарска наковалня за сладкодумство” (познато също просто като „Наковалня“). Той иска да се запази националният характер на българския език, но същевременно да може да се сравнява с останалите модерни европейски езици. Последното списание на Иван Богоров излиза само в седем броя. То съдържа много негови забележки и поуки към езика. Главният от факторите, които го карат да създаде това списание е руското влияние върху българския език, което по това време става по-силно от всякога. „Чистобългарска наковалня за сладкодумство” е до голяма степен отговор на пловдивския вестник „Марица", който употребява многобройни русизми в своите статии. Иван Богоров в своето списание взима примерни русизми от този вестник и ги анализира. Например в първия брой на списанието си поучава, че използваната дума грози (вместо плаши или сплашава) означава „стои грозно, не хубаво”. Той също препоръча на този вестник използването на български думи вместо русизмите, като например челяд, честит и бъдни вместо семейство, щастие и бъдущи [Младенов 1929]. Главната цел на списанието е утвърждаването на говоримия език като литературен и също заместването на чуждиците с родни думи. Този выпрос също го кара да пише Словница за изучванье на народниа наш язык от 1879 година и Бранилник на българскыа народен язык и за народна облага от 1880 година. Любопитен е фактьт, че „Чистобългарска наковалня за сладкодумство“ е първото българско списание, издадено след освобождението на България [Константинов, Минков, Великов 1961: 95; Коларов 2009: 59].

Както написах в началото: Иван Богоров създава повече списания. Няколко от тях нямат толкова голямо влияние върху формирането на българската преса или са просто продължение на по-ранните и по-популярните, като „Български орел” или „Цариградски вестник”, обаче сред тях има и такива, които полагат основите на тематичните списания. Добър пример на този въпрос е „Журнал за наука, занаят и търговия”. Той е издаван в три броя през 1862 година в Пловдив. Въпреки че списанието повдига вече познати теми е възприемано като първото икономическо списание на български език, тъй 
като е цялостно посветено за тази тема - предишните списания я анализират само спорадично. Иван Богоров го създава, защото твърди, че неговите теми са гаранти за прохождащите държави в модерността и за това списанието може да бъде панацея за българското бъдеще. „Журналът за наука, занаят и търговия“ коментира техническия прогрес и връзките между икономиката и науката. В него се появяват статии за индустриални изобретения, земеделие, история на икономически сдружения и компании в Европа и други. Трябва да се отбележи, че списанието не постига голям успех, тъй като неговият сюжет не съответства на тогавашното мислене на българите [Младенов 1929; Гетова 2008]. Любопитен е фактът, че заглавието на списанието съдържа думата журнал, която е използвана вместо българската вестник. Можем да забележим, че българската дума не е съвсем улегнала [Коларов 2009: 49].

Иван Богоров като автор на първите български вестници не само популяризира пресата в България, но също дава възможност на другите автори да разпространяват възрожденските идеи сред българите. След първото издание на „Български орел” не се появяват много нови вестници на български език, обаче след популярността на „Цариградски вестник” другите автори започват да издават и своите списания в духа на Възраждането. Добър пример за този въпрос е например журналистическата дейност на Петко Славейков, който издава две познати списания: „Смешна китка” (1852) и „Македонія” (1866). Богоровото влияние върху него е свързвано с тяхното сътрудничество във вестниците „Цариградски вестник“, „Турция“ и „Български книжици“. През 1877 година Павел Бобеков, Иван Адженов и Михаил Тенев издават „Секидневний новинар” - това е първият български всекидневен вестник. Журналистическата дейност на Иван Богоров също оказва влияние върху първото списание, написано на македонски литературен език, тоест „Вардар” от 1905 година редактирано от Кърсте Мисирков. Целият живот на Иван Богоров е посветен на развиването на пресата в България - не само информационна, но също тематична. Трябва да се отбележи, че дейността на Иван Богоров не е само свързвана с българската преса, медицината и езикознанието, но също и до известна степен с популяризацията на българската литература, давайки на автори като Петко Славейков, Йордан Хаджиконстантинов Джинот, Сава Филаретов или Константин Миладинов възможност за публикуване на творчеството си. Въпросът за българската преса (включвайки дейността на Иван Богоров) е многократно изследван от български учени - например Елена Гетова, Георги Борушков или Стефан Младенов. Трябва да се подчертае, че този вьпрос е привлекателен не само за българите, но също и за хората от други страни. Изследването на историята на българската преса е тема на научните работи например на поляците Зигмунт Млинарски (на полски Zygmunt Młynarski), Tереса Домбек-Виргова (на полски Teresa Dąbek-Wirgowa) или германката Клаудия Вебер (на немски Claudia Weber). Въпреки че разполагаме с много такива работи, трябва да се отбележи, че те обикновено са част от разработки за цялата епоха, а не точно за пресата и затова един нов по-детайлен прочит би помогнал за проучването на този въпрос. 


\section{Библиография}

Crampton R. J. (1997), A Concise History of Bulgaria, Cambridge University Press, Cambridge.

Dąbek-Wirgowa T. (1980), Historia literatury bułgarskiej, Zakład Narodowy imienia Ossolińskich, Wrocław.

Młynarski Z. (1962a), Historia prasy butgarskiej w krótkim zarysie, [в:] Z. Młynarski, I. Csapláros, Historia prasy czeskiej, stowackiej, wegierskiej i butgarskiej, Wydawnictwa Uniwersytetu Warszawskiego, Warszawa.

Młynarski Z. (1962b), Historia prasy czechosłowackiej, [в:] Z. Młynarski, I. Csapláros, Historia prasy czeskiej, słowackiej, węgierskiej i butgarskiej, Wydawnictwa Uniwersytetu Warszawskiego, Warszawa.

Wasilewski T. (1988), Historia Bułgarii, Zakład Narodowy imienia Ossolińskich, Wrocław.

Weber C. (2006), Auf der Suche nach der Nation. Erinnerungskultur in Bulgarien von 1878-1944, Lit, Berlin.

Боршуков Г. (1975), История на българската журналистика 1844-1877, 1878-1883, Наука и изкуство, София.

Георгиев Е. (1980), Люлка на старата и новата българска писменост, Народна Просвета, София.

Гетова Е. (2005), Вестникът като учебник, [в:] Научен сборник по повод 180-годишнината на „Рибния буквар”, Летера, Пловдив.

Гетова Е. (2008), Богоров - Русо. (Не)възможни паралели, Институт по балканистика и Френски културен институт, София, http://bulgc18.com/Rousseau/Elena_Guetova_bg.htm [достьп: 2.10.2018].

Каравелов Л. (1985), Събрани съчинения в дванадесет тома, т. 6, Български писател, София.

Коларов С. (2009), Из историята на българската журналистика. Документални статии u портрети, Университетско издателство „Св. св. Кирил и Методий“, Велико Търново.

Константинов Г., Минков Цв., Великов Ст. (1961), Български писатели. Биографии. Библиография., Български писател, София.

Леков Д. (2003), История на литературата и на възприемателя през Българското възраждане, т. I, Софийски Университет „Св. Климент Охридски”, София.

Младенов С. (1929), Иван Богоров, [в:] ред. М. Арнаудов, Български писатели: живот-творчество-идеи, т. I, Факел, София https://liternet.bg/publish7/smladenov/ibogorov.htm [достъп: 14 февруари 2018].

Мутев Д. (1858), Блъгарскы книжици: Повременно списание на Блъгарскљ-тљ Книжнинљ, Книгопечатницата на Д. Цанкова и Б. Миркова, Цариград.

Радев И. (2007), История на българската литература през Възраждането, Абагар, Велико Търново. 


\title{
Лех Церан
}

\section{THE CONTRIBUTION OF IVAN BOGOROV TO THE FORMATION OF THE BULGARIAN PRESS IN 19TH CENTURY}

\begin{abstract}
(Summary)
Ivan Bogorov is not only the one of the first Bulgarian journalists, but he is also one of the most important ones. He create several important newspapers and magazines like for example "Bălgarski orel" (bg. "Bulgarian eagle"), "Carigradski vestnik" (bg. "Tsargrad journal") and "Bălgarski knižici" (bg. "Bulgarian books"). His activity in this field not only created the direction of the development of the Bulgarian press, but also was popularising Bulgarian bookcraft by giving an opportunity of publishing works to authors such as Petko Slavejkov, Jordan Hadžikonstantinov Džinot, Sava Filaretov and Konstantin Miladinov. Thanks to the activists like Ivan Bogorov Bulgarian journalism achieved fast growth and in the period of few years has been aligned with the older and developed presses in Europe, like for example Czech one.
\end{abstract}

Key words: press, journalism, newspapers, magazines, history 